\title{
Borys Szumański
}

\section{Translacja i emancypacja}

\author{
K $\begin{array}{lllllll} & \mathrm{r} & \mathrm{y} & \mathrm{t} & \mathrm{Y} & \mathrm{K} & \mathrm{i}\end{array}$ \\ Wte i wewte. Z tłumaczamio prze- \\ kładach, red. Adama Pluszka, sło- \\ wo/obraz terytoria, Gdańsk 2016
}

ne w ciągu ostatnich 30 lat na łamach „Literatury na Świecie”, które poświęcone były pracy nad przekładem. W tym sensie książka Adama Pluszki wraz z pojawiającą się niemalże równolegle książką Zofii Zalewskiej Przejęzyczenie. Rozmowy o przekładzie ${ }^{3}$ stanowią precedens na tle polskiej tradycji mówienia o tłumaczeniu. Oto pojawiła się przestrzeń dla innego, bardziej swobodnego i dialogowego rozmawiania o przekładzie. Obok kwestii stricte translatorskich Pluszkę interesuje także stosunek tłumaczy do opracowywanych teksów, uczucia, które towarzyszą im podczas tłumaczenia oraz szeroko rozumiane społeczne, ekonomiczne, kulturowe i warsztatowe okoliczności ich pracy. Redaktor pyta o polityczny kontekst publikowanych tłumaczeń, o kulisy współpracy z wydawcami i redaktorami, o tłumaczenie szczególnie soczystych czy kłopotliwych zdań i tekstów. Ostatecznie jednak tym, co najbardziej uderzajacce jest nawet nie tyle charakter poruszanych tematów i sposób mówienia o nich, ale właściwie sam fakt włączenia rozmów na temat przekładu do ogólnego nurtu kultury.

Jeszcze do niedawna przekład nie budził większego zainteresowania poza kręgiem tłumaczy i specjalistów zajmujących się badaniami prze-

${ }^{3}$ Z. Zalewska, Przejęzyczenie. Rozmowy o przekładzie, Wołowiec 2015. 
kładoznawczymi. Temu kluczowemu dla rozwoju kultury zjawisku poświęcano niewspółmiernie mało uwagi, sytuując je na marginesie mówienia i myślenia o komunikacji literackiej. Dziś książki sprofilowane tak jak tom opracowany przez Zofię Zalewską czy Adama Pluszkę zdają się odpowiadać na pewne społeczne czy wręcz kulturowe zapotrzebowanie. Co się zatem zmieniło w odbiorze literatury przekładowej? Przeciętni jej czytelnicy wciąż skłonni są przez pojęcie przekładu rozumieć tekst-paradoks, który zastępuje oryginał i - choć brzmi i wygląda zupełnie inaczej niż ten ostatni - jest sygnowany nazwiskiem jego twórcy. Ostatnimi czasy wszakże coraz częściej dostrzega się i uznaje w akcie przekładu obecność osoby tłumacza, czemu sprzyjają różne akcje marketingowe na rynku książki, nagłaśniane nagrody translatorskie itp. Dzięki temu jesteśmy jako czytelnicy coraz bardziej skłonni zauważać i doceniać to, że w tłumaczenie, w uświęconą przez tradycję relację między oryginałem a przekładem wkrada się jeszcze trzeci element - tłumacz i jego język - który zakłóca ją, problematyzuje, ale i urozmaica. Odbiorczo dojrzewamy więc, by uznać przekładowość przekładu, rozpoznać nieoczywistość procesu przekładania i zacząć formułować pytania o jego przebieg i uwarunkowania.

Tom opracowany przez Adama Pluszkę pełni podwójną funkcję - jest zarazem heroldem i konstruktorem nowego kształtu dyskursu o przekładzie, zdaje sprawę z zachodzących przemian i ukazuje szeroki wachlarz perspektyw. Wte $i$ wewte pokazuje niewydolność paradygmatu mówienia i myślenia o przekładzie, w którym tłumacz znika, a jego praca ma charakter odtwórczy. Stanowi odpowiedź na społecznie przeczuwaną potrzebę lepszego zrozumienia węzłowego dla współczesnej kultury zjawiska, jakim jest tłumaczenie. Zarazem także taką potrzebę stwarza poprzez pluralizację perspektyw, która pogłębia erozję narracji promującej przeźroczystość tłumaczenia oraz niewidzialność tłumaczy i tłumaczek. Każda z siedemnastu rozmów Wte i wewte jest właściwie zapisem poszukiwania języka dla mówienia o przekładzie. To zarazem ekscytujący i karkołomny proces. Kryzys myślenia o przekładzie jako pewnej oczywistości, o zajęciu czysto technicznym, odsłania to, co w doświadczeniu tłumaczy obecne od zawsze - kwestię enigmy tłumaczenia. Mowa o niej m.in. w rozmowie z Elżbietą Tabakowską:

Przekład kongenialny, czyli równy oryginałowi, tak? Ale jak niby tę równość stwierdzić? Nie da się sporządzić pełnego inwentarza znaczeń dzieła. To nie jest kuferek z przejrzystą, raz na zawsze ustaloną zawartością. To raczej taki magiczny kuferek - ilekroć go otwieramy, za każdym razem znajdujemy coś nieoczekiwanego, czego przedtem się nie dostrzegło. Mogę się starać ile sił, penetrować wszystkie dostępne zakamarki, ale moje odczytanie, a zatem także mój przekład, nigdy nie wyczerpie wszystkiego, co jest w kuferku. Pojawią się inne interpretacje, nowe odczytania, kolejne odkrywcze przekłady. I całe szczęście (s. 144).

Zakwestionowanie przez Tabakowską - znakomitą tłumaczkę i zarazem badaczkę przekładu - fantazji o kopii doskonałej nie tylko ukazało nieoczywistość dostępności sensów oryginału, ale uwrażliwiło na pytanie, jak tłumacz czy tłumaczka się wobec tej nieoczywistości opowiada? Jak sobie $z$ nią radzi? Jakie manewry i strategie stosuje, by wytworzyć efekt, który nazywamy przekładem i za przekład gotowi jesteśmy uznawać? W istocie uruchomione zostało pytanie o podmiotowość tłumacza. Ta kluczowa kwestia, o podniesienie której od lat coraz głośniej apelują teoretycy przekładu - warto wymienić w tym miejscu chociażby Lawrenca Venuttiego, Douglasa Robinsona i Andrew Chestermana, a w Polsce m.in. Jerzego Jarniewicza i Magdę Heydel - w książce Pluszki zyskuje artykulację. Zbiór wywiadów, w którym to przede wszystkim tłumaczom i tłumaczkom oddaje się głos, jest zapisem prób upodmiotowiania tego głosu, a wraz z nim także własnej pracy 
twórczej. Wte $i$ wewte daje szerokie wyobrażenie na temat roli, jaką $w$ procesie tłumaczenia odgrywa osoba tłumacza: jego psychika, kontekst, w którym tworzy, warunki kulturowe, społeczne i ekonomiczne. Pokazuje osobiste i kontekstualne kulisy translatorskich decyzji, które mają realny wpływ na ostateczny kształt przekładu oraz, w konsekwencji, literatury w języku rodzimym.

Zarazem książka Pluszki zdaje sprawę z trudności, jaką jest mówienie o doświadczeniu tłumaczenia. Z jednej strony $w$ wypowiedziach tłumaczy łatwo dostrzec ślady ich własnych przemyśleń, metaprzekładowych refleksji formułowanych w obliczu zaskakujących problemów i szczególnie dotkliwych translatorskich trudności. Pojawia się więc pole dla translatorskich wspomnień, anegdot, warsztatowych pogadanek. Z drugiej zaś w przywoływanych metaforach, porównaniach, konceptach łatwo wychwycić okruchy i echa rozmaitych dyskursów, systemów filozoficznych i teoretycznych, porządkujących i dyscyplinujących mówienie o przekładzie. Nie brak więc także rozważań ustrukturowanych, odwołujących się do konkretnych nazwisk i konkretnego zaplecza myślowego. Na przecięciu tych dwu ścierających się i wchodzących we wzajemne zależności porządków: osobistego i powszechnego, czy jak powiedziałby Douglas Robinson ${ }^{4}$ - idiograficznego i ideograficznego - konstruowana jest odpowiedź na pytanie o enigmę tłumaczenia, która nazywana bywa różnie (oryginałem, tajemnicą, obcością, różnicą), a która każdorazowo stanowi istotny aspekt podmiotowości tłumacza i rozumienia przez niego (i przez innych) swojego zadania.

Przywołajmy w tym miejscu trzy szczególnie ciekawe w moim odczuciu wypowiedzi, które pojawiły się na kartach Wte $i$ wewte. Oprócz wartości egzemplifikacyjnej głosy te będą mia-

\footnotetext{
${ }^{4}$ D. Robinson, The Translator's Turn, Baltimore-London
} 1991. ły dla mnie znaczenie kategoryzacyjne. Chciałbym je bowiem uporządkować według klucza malejącego udziału idiograficznych i rosnącego udziału ideograficznych aspektów wypowiedzi, systematyzując $w$ ten sposób spektrum postaw, które można odnaleźć w książce Adama Pluszki. Na początek fragment rozmowy z Maciejem Świerkockim:

A mówiąc całkiem serio, uważam, że przekład [...] potężnych objętościowo książek jest dla tłumacza komfortem i przyjemnością, bo po pierwsze, ma zajęcie na wiele długich miesięcy i nie musi się zbyt szybko martwić o szukanie następnego, a po drugie, może sobie swobodnie pływać po tekście - albo raczej zanurzyć się w nim, zgubić i w rezultacie zapomnieć na dłuższy czas o coraz ciaśniej otaczającej nas rzeczywistości, pełnej głupoty i chamstwa, od której ja zdecydowanie wolę światy fikcyjne (s. 22).

Dla Macieja Świerkockiego przekład ma wymiar eskapistyczny, ale i przyjemnościowy. O obu aspektach rzadko mieliśmy okazję słyszeć w dotychczasowym dyskursie o przekładzie. Wypowiedź Świerkockiego przenosi przekład w domenę fantazji i twórczości. W istotny sposób odwraca perspektywę - zaprasza do zadawania pytań już nie o rolę, jaką osobowość tłumacza odgrywa dla kształtu przekładu, ale o to, jaką rolę odgrywa przekładanie w formowaniu osobowości tłumacza. Enigma tłumaczenia zostaje tutaj ściśle powiązana z enigmą egzystencji tłumaczącego.

Z kolei fragment rozmowy z Barbarą Kopeć-Umiastowską:

Zdarza się, że tekst niesie tłumacza, energia oryginału jest taka, że przekład właściwie robi się sam. Im lepsza książka, tym częściej tak się dzieje, bo wtedy większa jest wartość dodana, nieredukowalna do elementów widzialnych - leksyki, składni i stylu. Jest coś nadprzyrodzonego we władzy, jaką język miewa nad człowiekiem, i może lepiej zanadto $w$ to nie wnikać - i do końca mu nie ufać, bo potrafi wywieść na manowce (s. 130). 
W wypowiedzi tłumaczki, podobnie jak w wypowiedzi Macieja Świerkockiego, również wybrzmiewa rzadko słyszany ton związany z przyjemnością tłumaczenia. Większą wagę jednak Barbara Kopeć-Umiastowska zdaje się przywiązywać do „wartości dodanej” i „nadprzyrodzonej mocy”, która w kontekście przekładu wiąże się z medium języka. To aspekt przekładu, na którego ważność uwrażliwiły nas już wcześniej hermeneutyczna i lingwistyczna myśl teoretyczna. W narracji tłumaczki dochodzi jednak do ich szczególnego mariażu, rodzącego nową wartość: zadziwienia władzą, jaką język roztacza nad tłumaczem w akcie przekładu. To temat, który w różnej postaci, ale w dużym natężeniu pojawia się $w$ wielu rozmowach przeprowadzonych przez Adama Pluszkę. Enigma tłumaczenia zostaje tu powiązana z tajemniczą mocą języka.

I wreszcie fragment rozmowy z Dariuszem Żukowskim:

Coetzee zastanawia się w pewnej scenie z autobiograficznej powieści nad nieśmiertelnością, a temat ten splata z istotą pracy. Pisze o nieśmiertelności robotnika, który wylał betonowy blok. Trochę mu jej zazdrości. Po wielu latach można podejść i pokazać palcem trwały efekt jego pracy. To duży paradoks, że ludzie, którzy wykonują prawdziwą, przydatna pracę są najniżej wynagradzani, a jacyś spekulanci giełdowi i inne pasożyty z finansjery śpią na absurdalnych pieniądzach. A kim jest tłumacz w tym wszystkim? Tłumacze i inni przetwarzacze symboli - zwłaszcza naukowcy humaniści - wymyśliliśmy rozbudowany dyskurs, który ma uzasadniać ich rzekomo ważną rolę oraz roszczenia do niezależności od wszystkiego, w tym od mierzalnych standardów przydatności pracy. A przekład wyjątkowo dobrze nadaje się do przestawiania w kategoriach wiedzy tajemnej. W pewnym sensie nią jest, jeśli wziąć pod uwagę hermeneutykę czy wręcz mistykę przekładu rozwijaną od starożytności i starającą się zgłębić, najogólniej mówiąc, nierozwiązywalną zagadkę ekwiwalencji słów i istoty języka (s. 98).
Odwołując się do kategorii pragmatycznych i rynkowych, Dariusz Żukowski zadaje pytanie o wartość pracy tłumacza w nowej rzeczywistości społecznej. W swojej prowokacyjnej wypowiedzi unieważnia kwestię enigmy tłumaczenia - mówi o niej jako dyskursywnym tricku, konstrukcie przywoływanym, by sztucznie podnosić prestiż pracy tłumacza. Mogłoby się wydawać, że wypowiedź Żukowskiego dąży do ponownego unieważnienia podmiotowości tłumacza. Zachęca, by widzieć w nim szarego pracownika, który ginie już nie schowany za oryginałem, ale w tłumie anonimowych wykonawców zrzeszanych przez agencje przekładowe. Bardziej niż o enigmie wytwarzanej przez tradycję hermeneutyczną Żukowski będzie skłonny rozmawiać o „niewidzialnej ręce rynku”. W przywoływanej przez niego narracji podmiotowość tłumacza ogniskowałaby się raczej wokół pytań dotyczących wymiany ekonomicznej aniżeli językowej.

Zacytowane wypowiedzi różnią się pod względem stopnia udziału w nich prywatnych przeżyć i przemyśleń tłumaczy, a także wyrazistości i świadomości dyskursów o przekładzie, które w sposób mniej lub bardziej wyraźny stanowią ich zaplecze. Szczególnie wyczulony na tę kwestię wydaje się Dariusz Żukowski, który podkreśla rolę dyskursu w konstruowaniu społecznego obrazu tłumacza. Wskazuje on, że społeczne i zawodowe istnienie tłumaczy i tłumaczek jest wręcz zdeterminowane przez dominujące w kulturze tendencje myślenia i mówienia o przekładzie. Prestiż, ale też natura pracy tłumacza, jej definicja i wartość efektów są wyznaczane przez społeczne narracje. Taka diagnoza oczywiście nie unieważnia kwestii podmiotowości, ale przydaje jej bardziej dramatycznego charakteru. „A kim jest tłumacz w tym wszystkim?" - pyta Żukowski, dając wyraz poczuciu zagrożenia translatorskiej tożsamości i domagając się uprawomocnienia, usensownienia, społecznego zakorzenienia instytucji przekładu. 
To bardzo ważny sygnał, który zresztą pobrzmiewa - choć już nie tak mocno - w wypowiedziach wielu innych tłumaczy w omawianej książce. Tom ten zbiera bowiem ślady refleksji, które pojawiaja się w dobie przejścia i w obliczu rozchwiania. Kryzys dawnego dyskursu o przekładzie, jest - rzecz jasna - szansą na emancypację tłumaczy i tłumaczek. Sprzyja wyłanianiu się ich głosów, konstruowaniu społecznych translatorskich tożsamości. Stanowi jednak również zagrożenie. Z jednej strony jest to zagrożenie kolejnym odpodmiotowieniem, tym razem przez mechanizmy rynkowe, które z niepokojącą łatwością zajmują coraz to nowe tereny, powodując u tłumaczy poczucie alienacji. Z drugiej strony natomiast pojawia się groźba, że tłumacze i ich praca znajdą się w próżni, a sam fenomen przekładu - choć we współczesnym świcie odgrywa tak istotną rolę - stanie się coraz bardziej wątpliwy, chwiejny i łatwiejszy do zakwestionowania. W efekcie pojawia się lęk o własną pozycję i znaczenie. W tym kontekście książka Adama Pluszki staje się poligonem, na którym z różną siłą ścieraja się rozmaite narracje na temat przekładu, ale także otwartym polem dla dyskusji o szansach nowego uprawomocnienia i zakotwiczenia zawodu tłumacza.

W związku z tym na uwage zasługuje jeszcze jeden, osiemnasty głos tłumacza, który pojawia się w Wte $i$ wewte w formie paratekstu. Jerzy Jarniewicz, autor wstępu do tej książki, tłumacz i teoretyk przekładu, w obliczu sytuacji kryzysowej odwołuje się do mitu i próbuje wypracować dla tłumaczy i tłumaczek zręby nowej tożsamości, z jednej strony pozwalającej zorientować się w nowej sytuacji i tym samym zredukować lęki, a z drugiej oddającej sprawczość w ich ręce i motywującej do działania. W krótkim szkicu zatytułowanym Antygony wracają, albo o emancypacji przekładu literackiego Jarniewicz poprowadził paralelę między emancypacyjną sytuacją współczesnych łłumaczy oraz wciąż trwającymi procesami emancypacji ko- biet (jak sam podkreślał, związek ten jest niejako naturalny ze względu na obecność i znaczenie w historii - zarówno historii powszechnej, jak i historii przekładu - kobiet zajmujących się tłumaczeniem). Podkreślił tym samym po raz kolejny związek dyskursu o przekładzie i dyskursu feministycznego, uwypuklając szczególne jego aspekty. Przekład w obliczu słabnącej fallogocentrycznej kultury, fetyszyzującej relację podobieństwa i negującej różnicę nieuchronnie pojawiająca się w przekładzie, przypomina kobietę domagającą się wyjścia poza pułapki binarnego myślenia i wypracowania własnej, pozytywnej tożsamości:

\footnotetext{
[...] jest tu coś istotniejszego na rzeczy, a mianowicie postrzeganie przekładu jako czynności nietwórczej, ale odtwórczej, pasywnej, wtórnej, podporządkowanej, służebnej. Wystarczy spojrzeć na listę tych przymiotników, by uświadomić sobie, że są to określenia współtworzące dyskryminacyjny stereotyp kobiecości (s. 11).
}

Stawka - jak to zwykle w kontekście przekładu bywa - ulega podwojeniu. Z jednej strony idzie tu o uprawomocnienie przekładu jako aktu twórczego, zakotwiczonego w znacznie szerszym kontekście niż tylko odniesienie do oryginału. $Z$ drugiej strony natomiast gra toczy się o uznanie i uprawomocnienie podmiotowej obecności tłumaczy i tłumaczek w ich twórczej pracy nad przekładem, o prawo do bycia widocznym zarówno w przekładzie, jak i w przestrzeni społecznej. Tradycyjny dyskurs o przekładzie wprowadzał niepisane prawo, które nakazywało tłumaczom społeczne i twórcze samounicestwienie - zadaniem tłumacza było zniknąć. Nie pokazywać się w przestrzeni tekstu. Podobnie zadaniem kobiety było opiekowanie się domowym ogniskiem, które stanowiło zaplecze podtrzymujące funkcjonowanie społeczeństwa, przy równoczesnym niepokazywaniu się w przestrzeni publicznej. Osoby zajmujące się tłumaczeniem - pamiętajmy też o redaktorach i redaktorkach - tak jak kobie- 
ty w patriarchacie miały gwarantować istnienie systemu przy równoczesnym pozostawaniu na jego marginesie czy wręcz poza jego granicami. Zarysowując paralelę w ten sposób, Jarniewicz wykonał ważną pracę: nie tylko pomógł za pomocą metafory zorientować się tłumaczom i tłumaczkom w ich sytuacji, ale także uzbroił ich zestaw pojęć i odniesień, wyznaczając możliwy kierunek działań:

Powiedzmy wprost: tłumacze mają dziś na imię Antygona. Są jak córka Edypa, choć szczęśliwie nie dzielą jej tragicznego losu. Oczekuje się od nich, że będą wierni oryginałowi, za tę wierność są rozliczani. Że do stanowienia prawa się nie przyłożą, a zamiast tego będą wypełniać, co każe im tego prawa tekst. Tymczasem coraz częściej stanowią prawo (s. 14).

Uświadamianie sobie i negocjowanie warunków własnego istnienia oraz tworzonych przez siebie przekładów stanowi sedno budowania translatorskiej tożsamości i podmiotowości. Osoby działające w "strefie przekładu”, sytuujące się na pograniczach języków i dyskursów są szczególnie predysponowane do wykonywania tej pracy, ale ze względu na jej trud pozostają także narażone na przyjmowanie łatwych i redukcjonistycznych rozwiązań, których konsekwencje ponoszą nie tylko one same, ale także czytelnicy. Powiedzenie, że na barkach tłumaczy i tłumaczek spoczywa odpowiedzialność za kształt kultury docelowej i jej relacje z innymi kulturami, nie jest przesadą. Dziś wiemy już, że odpowiedzialność ta polega nie tyle na wierności wobec oryginału, ale na świadomym stosunku do różnych instancji, które determinują sytuację przekładową. Praca ta odbywa się także na bardzo podstawowym poziomie - drobnych translatorskich decyzji, świadomości stosowanych rozwiązań, wypracowywania trudnych kompromisów, ale także

\footnotetext{
${ }^{5}$ Określenie zaczerpnięte z tytułu książki Emily Apter, The Translation Zone. A New Comparative Literature, Princeton 2006.
}

prowadzenia dyskusji na temat kształtu i znaczenia przekładu.

Rozmowy zebrane przez Adama Pluszkę, choć prowadzone z profesjonalistami, mają ostatecznie charakter popularyzatorski, co stanowi ich zaletę. Wiele z pojawiających się w książce wypowiedzi ma status anegdoty, wspomnienia, osobistej refleksji, często płyną one torem dygresyjnym. Siła tej publikacji jest jej nieoficjalność, żywiołowość, pluralizm zebranych głosów, pokazanie nowych, bardziej swobodnych sposobów mówienia o przekładzie, upublicznianie i uwspólnianie dyskursu. Jej lektura daje przyjemność i satysfakcję, a ukazując blaski i cienie translatorskiej profesji, budzi nią zasłużone zainteresowanie. 


\title{
SŁOWA KLUCZOWE:
}

\author{
feminizm \\ PRZEKEAD
}

krytyka przekładu

\begin{abstract}
AbStrakT:
Artykuł omawia książkę Adama Pluszki, Wte i wewte. $Z$ tłumaczami o przekładach. Na podstawie wybranych fragmentów publikacji podejmuje kwestię prywatności tłumaczy i tłumaczek oraz - rozumianego psychoanalitycznie - pragnienia w procesie przekładu. Pokazuje możliwe realizacje przekładowego pragnienia oraz podkreśla konieczność - dostrzeganą także przez samych tłumaczy i teoretyków przekładu - „emancypacji” tłumaczy i tłumaczek.
\end{abstract}




\section{psychoanaliza}

\section{NOTA O AUTORzE:}

Borys Szumański - doktorant na Wydziale Filologii Polskiej i Klasycznej UAM, student psychologii. Przygotowuje rozprawę doktorską, pt. „Dyskurs o przekładzie w świetle teorii psychoanalitycznych". 